\title{
USING INCIDENTAL VOCABULARY ACQUISITION TO ENRICH THE STUDENTS VOCABULARY MASTERY
}

\section{Pemanfaatan Pemerolehan Incidental Vocabulary Untuk Memperkaya Penguasaan Kosakata}

\author{
St. Asmayanti \\ English Education Department, Faculty of Teacher Training and Education \\ Muhammadiyah University of Makassar
}

\begin{abstract}
The research aimed to find out the improvement the students'vocabulary in terms of improving their understanding about of nouns and adjectives. To explain the increase, the researcher used a classroom action research (CAR) which was conducted in two cycles in which each cycle consisted of four meetings. The subject was the students at the eight grade of SMP Askari Pallangga Gowa. The number of sample consisted of 37 students. The research findings indicated that using Incidental Vocabulary Acquisition could improve the students' vocabulary of noun and adjective.It was prove by the result of diagnostic test, the students' mean score got was 53.78. After applying the Incidental Vocabulary Acquisition in cycle I, the students' achievement increased to be 63.6. In cycle II the students' vocabulary increased to be 85 .
\end{abstract}

Keyword: vocabulary, incidental vocabulary

Vocabulary has an important role in all aspects of language skills. The vocabulary as one of the elements of language is important to study, because without enough vocabulary mastery, the ability to communicate and to convey cannot be established.

According to Harmer (1991:115), we must have something to say; we must have meanings that we wish to express, and we need to have a store of words that we can select from when we wish to express the meaning. Allan (1997:149) argues that vocabulary is an important factor in all language teaching. Besides, the sound system and structure the other essential area of language learning is the lexicon, or vocabulary command of the language in order to master the English language, the students have to know the importance of English vocabulary. Many students cannot read and understand the text because they do not have a good vocabulary command.

One of the strategies which can be used in teaching English vocabulary is Incidental Vocabulary acquisition. Teaching vocabulary by 
using Incidental Vocabulary Acquisition is suitable to improve vocabulary mastery of the students, because trough this strategy, the students can find new words. Besides, Incidental Vocabulary is provides activities which help the students to remember the materials. Furthermore, using this strategy, it gives enjoyful and fun for the students who are learning English vocabulary.

\section{The Concepts of Incidental Vocabulary Acquisition}

\section{a. Definition of the Incidental Vocabulary Acquisition}

Incidental Vocabulary Acquisition is a vocabulary learning strategy, defined as the learning of new words as a by-product of a meaning-focused communicative activity, such as vocabulary. It occurs through multiple exposures to a word in different contexts (Huckin and Coady, 1999:185).

In order to understand the present state of vocabulary acquisition research, it is important to consider how vocabulary instruction has been regarded in the past, The history of vocabulary study in language teaching has seen various movement over the countries. If one were to look at the many recent articles on the subject, one might conclude that vocabulary is only now receiving any serious attention in the field of second language research. In some ways it may be true. The role of vocabulary in language teaching does have some what of an interesting, if not unremarkable past.

The other potential of incidental vocabulary acquisition are the contextual richness in which a word is found, and the number of appearance of a word in a text. There is evidence that not "ever context is an appropriate on effective means for vocabulary development "(Beck, Mc Keown and Mc Cuslin, 1983:162). The order aspects of second language acquisition, naturally, through exposure to comprehensible impute a meaningful context (krashern 1989:75).

Coady (1993:83) also observes that interest that vocabulary has recently undergone resurgence and he attributes this to the drive for 'academic' ability in English as a second language. This movement for academic English has instigated some scholar to argue for formal direct 
vocabulary instruction. For example, claiming that not all Vocabulary Acquisition should be left to incidental contact in context.

Richard' oft-cited 1976:58 article, The role of Vocabulary Teaching, called for more research into vocabulary acquisition. At the time, Richards knowledge that the study of teaching and learning vocabulary had "never aroused the same degree of interest within language teachings have such issues as grammatical competence, contrastive analysis, reading or writing, which have received considerable attention from scholars and teacher".

Coady (1986:172) contended that "vocabulary learning is a mastery and paradox". The mystery to which Coady alludes refer to the fact for years teacher have assumed that incidental vocabulary learning does take place from reading yet "there is no clear cut research demonstrates how such contextual learning take place." On one side of the paradox, Coady states that less frequent vocabulary is almost exclusively encountered through reading. On the other side, often second language readers do not have enough initial vocabulary to read well enough to learn.

In the category of Vocabulary Acquisition and Reading Research, Coudy specifically looks at the vocabulary required for reading comprehension to take place. He states that methods of developing a base vocabulary should be explored, perhaps through direct interaction. Consequently, numerous studies fall under the category of "vocabulary and reading research" which address various features of vocabulary acquisition through reading.

Hirsh and Nation several methods which they argue may help learners to read unsimpliefied texts. The firs method they suggest is using slightly modified or simplified text on the assumption that small change in vocabulary difficulty can have significant influence in a leaner's ability to comprehend a text and learn new vocabulary. This suggestion appears reasonable and would seem to be an acceptable way of improving reading comprehension. This may be feasible for shorter stories with smaller number of unknown word. 
The article to be reviewed in this section is one by Beck. Mckeown and Mc Caslin (1983:35). They are quick to point out but not all contexts are sufficient to facilitate vocabulary acquisition. They claim that there are basically two types of context, a 'pedagogical context' in which the text is specifically design for teaching vocabulary and 'natural context' in which we find all other manner of text where the author ere not concerned with conveying the meaning of unknown words.

The research concluded that the majority of text do not provide adequately rich contexts for incidental vocabulary acquisition to take place. They propose that along with context, an effective method of vocabulary instruction is necessary for second language learners. The researchers content that leaving student to decode new word by the use of glossaries is basal readers is not a reliable method arguing that only the most enthusiastic students interrupted their reading to check on new word. This leaves the less enthusiastic, and probably the most needy student, behind. What the author suggest is that teacher discuss new word with students, have students keep a record of new word and also encourage student to use new word outside the confines of the classroom in their own writing and conversation.

\section{b. The advantages Incidental Vocabulary Acquisition}

1) It is contextualized, giving the learner a richer sense of a word's use and meaning than can be provided in traditional paired-associate exercises;

2) It is pedagogically efficient in that it enables two activities-vocabulary acquisition;

3) It is more individualized and learner-based because the vocabulary being acquired is dependent on the learner's own selection.

\section{RESEARCH METHODOLOGY}

This research was held around two cycles. Those were first and second cycle and each cycle was the series of activities which had a close relation. 
The realization of the second cycle is continued and repaired from the first cycle.

In this Classroom Action Research (CAR), the writer used CAR principle to collect the data. The research consisted of two cycles with each cycle consisted of four Stages; they were: Planning, Implementation of Action, Observation, and Reflection.

\section{Cycle I}

In this research, the writer took four meetings to finish cycle. The cycle I consisted of four steps namely: planning, action, observation and reflection. Every step is explained clearly as follows:

\section{Planning}

The activities in this stage as follows:

a. Studying and understanding the curriculum used in the eight students $2012 / 2013$.

b. Made lesson plan based on the Curriculum.

c. Made instruments which are used in this research.

d. Made the sheet for observation to see the condition of teaching and learning process when it is being continued.

e. Arranged tests to know the students' achievement toward the Using Incidental Vocabulary Acquisition method.

\section{Action}

a. The writer explained the method that apply in the research and the instructional objectives that will be achieved.

b. The writer explained the topic to discuss.

c. The writer gave questions to the students to dig their prior knowledge about the material.

d. The writer asked the students to sit in a pair and gives the materials which were practice.

e. The writer starts the learning process by stimulating the students through the questions referring to the topic were practice. 
f. The writer explains the way to do the material in pair and after that give chance to the students to practice it. During the practice, the research control and guide them.

g. At the end of the class, the writer asked the students toward the difficulties faced.

\section{Observation}

In this phase the writer observed the situation of teaching and learning process using observation sheets and done evaluation.

\section{Reflection}

The writer analyzed and evaluated all of the data, which had collected from observation activity to assess the teaching program achievement after giving an action at the first cycle.

After finishing the cycle I, the result of the learning process not significant to what the writer expect, so the cycle II toke for improvement of the cycle achievement.

\section{Cycle II}

In cycle 2 also consists of same activity with cycle 1 they are:

\section{Planning}

a. Continuing the activities that have been done in the first cycle.

b. Made lesson planning, prepare material and observation form for four meetings.

c. Repairing the weakness in the first cycle.

d. Repairing Action research.

\section{Action}

In this stage, action done to improve the result based on the reflection in cycle 1 . The stages have same procedure with different variation and material to reach target learning result.

\section{Observation}

In this phase the writer observed the situation of teaching learning and the students activity in teaching learning process to 
improve the result based on the reflection in cycle 1 by using observation sheets and do evaluation which use the result to know how far they the students improvement.

\section{Reflection}

The writer analyzed and evaluated all of the data, which had been collected from observation, to assess the teaching program achievement after giving an action at the second cycle.

\section{A. Research Variables and Indicators}

\section{Research Variables}

Remembering that variable is one of the very important elements of research, the writer used two kinds of variable; they were dependent variable and independent variable in wich one variable could influence the other.

a. The Independent Variable

Independent variable of this research is the using incidental vocabulary acquisition .

b. Dependent variable

Dependent variable was the students' improvement in vocabulary mastery.

\section{Indicators}

The indicators of the research was the students' vocabulary achievement in learning noun and adjective .

\section{B. Research Instruments}

In this research, the writer used two instruments to collect the data was used to observe and to record the students' participant in teaching learning process through incidental vocabulary acquisition. It was done in every cycle. It was summed at the end of cycle I and cycle II. It was designed to measure the students' development in reading comprehension ability after implementing action in each cycle. The test was administered in the last meeting of each cycle. 


\section{Technique of Data Collection}

The writer some procedures in collecting the data, such in the following:

1. Observation sheet

The writer used observation sheet to find out the students' activeness and presence during the teaching and learning process using observation sheet.

2. Test

The writer gave test to students to find out their development in understanding vocabulary. The writer used test namely vocabulary test. The tests were essay and multiple choice and were given in the end of each cycle.

In scoring the result of students' test the writer used the classification of scoring as follow :

\begin{tabular}{|c|c|}
\hline Indicator & Score \\
\hline Correct & 2 \\
\hline Incorrect & 0 \\
\hline
\end{tabular}

(Depdikbud, 1985:8)

\section{Data Analysis Techniques}

The data has been collected was analyzed through the following steps:

1. To classified the students' score, there are seven classifications which is use as follows:

$$
\begin{array}{ll}
\text { Score } 91-100 & =\text { very good } \\
\text { Score } 76-90 & =\text { good } \\
\text { Score } 61-75 & =\text { fairly } \\
\text { Score } 51-60 & =\text { poor } \\
\text { Score less than } 50 & =\text { very poor. (Debdikbud, 1985:6) }
\end{array}
$$

2. To find out the mean score of the students' test, the writer used the formula :

$$
\bar{X}=\frac{\sum X}{N}
$$

Where : 


$$
\begin{array}{ll}
\bar{X} & =\text { Mean Score } \\
\sum X & =\text { Total Score } \\
N & =\text { The number of students. (Gay, 1981:298) }
\end{array}
$$

3. To Calculate the percentage of the students' score, the formula which is use as follows:

$$
P=\frac{F}{N} X 100
$$

Notation :

$$
\begin{array}{ll}
\text { P } & \text { : Rate Percentage } \\
\text { F } & \text { : Frequency of the correct answer } \\
\text { N } & \text { : The total number of students. (Sudjana, 1990:36) }
\end{array}
$$

4. To know percentage of the students improvement by applying the following formula:

$$
\begin{aligned}
&(\mathrm{D}-\text { Test } \rightarrow \mathrm{CI}) P=\frac{X 1-(D-\text { test })}{D-\text { test }} X 100 \\
&(\mathrm{CI} \rightarrow \mathrm{CII}) \quad \mathrm{P}=\frac{X 2-\mathrm{X} 1}{X 1} X 100 \\
&(\mathrm{D} \text {-test } \rightarrow \mathrm{CII}) \quad P=\frac{X 2-(D-\text { test })}{D-\text { test }} X 100
\end{aligned}
$$

Notation:

P : Percentage of the students

$\mathrm{X} 1$ : first cycle

X2 : second cycle. (Sudjana, in Hamida, 2001:25)

5. To analyze the students' participation in research toward the material and activities in teaching and learning process by checklist. The students' active participation described followed:

\begin{tabular}{|l|l|c|l|}
\hline No & $\begin{array}{c}\text { The students' Active } \\
\text { Participation }\end{array}$ & Score & \multicolumn{1}{|c|}{ Indicator } \\
\hline 1 & Very Active & 4 & $\begin{array}{l}\text { Students' respond to the material } \\
\text { very active }\end{array}$ \\
\hline 2 & Active & 3 & $\begin{array}{l}\text { Students' respond to the material } \\
\text { actively }\end{array}$ \\
\hline 3 & Fairly active & 2 & $\begin{array}{l}\text { Students' respond to the material } \\
\text { just once or twice. }\end{array}$ \\
\hline 4 & Not active & 1 & $\begin{array}{l}\text { Students just sit down during the } \\
\text { activity without doing }\end{array}$ \\
\hline
\end{tabular}




\begin{tabular}{|l|l|l|l|}
\hline & & & something. \\
\hline
\end{tabular}

(Sudjana in Sahriani, 2010:31)

6. Percentage the students' participation through the following formula:

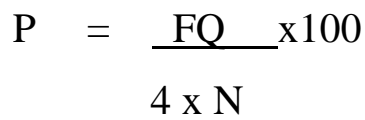

Where:

$\mathrm{P} \quad=$ Percentage

FQ $=$ Sum of all the students' score

$\mathrm{N} \quad=$ Total students.

(Sudjana in Suhadirman, 2010:40)

\section{FINDINGS AND DISCUSSION}

\section{A. FINDINGS}

\section{The Improvement of the Students' Vocabulary in Nouns and adjectives}

The application of Incidental Vocabulary Acquisition in Improving the students' Vocabulary of nouns. Each indicator had total score and it is divided by sum of students so it resulted as means score in D- Test, cycle I, and cycle II. So, the improvement of the students' vocabulary in nouns could be seen clearly in the following explanation:

Table 1: The improvement of the students vocabulary

\begin{tabular}{|c|c|c|c|c|c|c|}
\hline \multirow{2}{*}{ Indicator } & \multicolumn{3}{|c|}{ The student score } & \multicolumn{3}{c|}{ Improvement (\%) } \\
\cline { 2 - 7 } & D-test & Cycle I & Cycle II & DT $\rightarrow$ CI & CI $\rightarrow$ CII & DT $\rightarrow$ CII \\
\hline nouns & 54.32 & 64.86 & 86.49 & 19.40 & 33.35 & 59.22 \\
\hline adjectives & 53.24 & 62.43 & 83.51 & 17.26 & 33.76 & 56.85 \\
\hline$\sum X$ & 107.74 & 127.29 & 170 & 36.66 & 67.11 & 116.07 \\
\hline $\bar{X}$ & 53.87 & 63.65 & 85 & 18.33 & 33.55 & 58.03 \\
\hline
\end{tabular}

The table above indicated that there was improvement of the students' vocabulary from D-Test to cycle I and cycle II, where in D-Test the students' mean score achievement in learning vocabulary was 53.87 , but after evaluation in cycle I the students' vocabulary became 63.65 , so the improvement of students' vocabulary achievement from D-Test to cycle I was $18.33 \%$ while the improvement of students' vocabulary achievement 
from cycle I to cycle II was $33.55 \%$ and the improvement of students' vocabulary achievement from D-Test to cycle II was $58.03 \%$.

To see clearly the improvement of the students' vocabulary the following chart was presented:

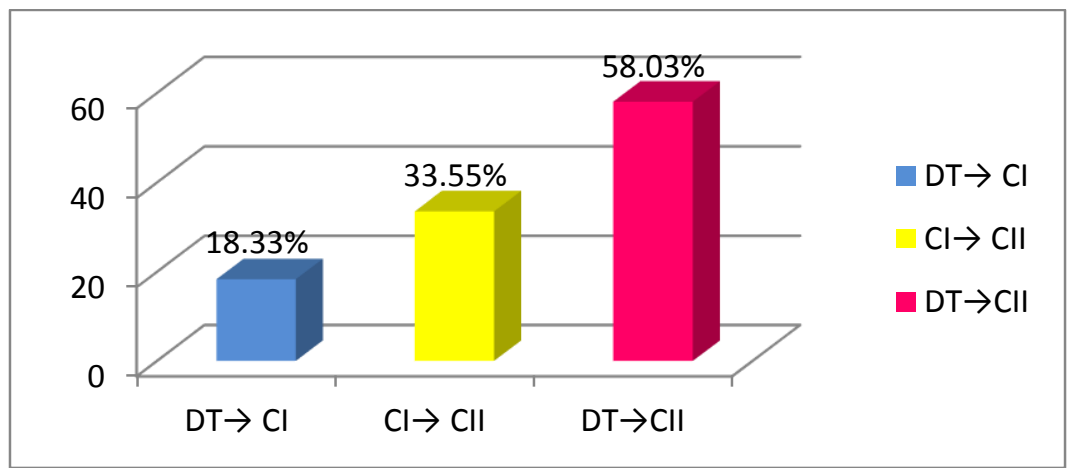

Chart I: The improvement of the Students' Vocabulary

The chart above showed the improvement of the students' vocabulary in d-test to cycle I was $18.33 \%$, cycle I to cycle II was $38.55 \%$ d-test to cycle II was $58.03 \%$.

\section{The percentage of the students vocabulary in using nouns}

After evaluation in cycle I and cycle II, there was an improvement of the students' vocabulary in using noun that shown clearly in the chart after taking an action in cycle through Incidental Vocabulary Acquisition method.

Table 2. Percentage of the Students' Vocabulary in using Noun

\begin{tabular}{|c|c|c|c|c|c|c|c|c|}
\hline \multirow{3}{*}{ No } & \multirow{3}{*}{ Classification } & \multirow{3}{*}{ Score } & \multirow{2}{*}{\multicolumn{2}{|c|}{$\frac{\text { Non FC }}{\text { D-test }}$}} & \multicolumn{4}{|c|}{ The Application of FC } \\
\hline & & & & & \multicolumn{2}{|c|}{ Cycle I } & \multicolumn{2}{|c|}{ Cycle II } \\
\hline & & & Freq & $\%$ & Freq & $\%$ & Freq & $\%$ \\
\hline 1 & Very good & $91-100$ & - & & - & & 5 & 13.51 \\
\hline 2 & Good & $76-90$ & - & & 3 & 8.11 & 30 & 81.08 \\
\hline 3 & Fairly & $61-75$ & 3 & $8.11 \%$ & 15 & 40.54 & 2 & 5.40 \\
\hline 4 & Poor & $51-60$ & 15 & $40.54 \%$ & 16 & 43.24 & - & - \\
\hline 5 & Very Poor & $0-50$ & 19 & $51.35 \%$ & 3 & 8.11 & - & - \\
\hline \multicolumn{3}{|c|}{ Total } & 37 & $100 \%$ & 37 & $100 \%$ & 37 & $100 \%$ \\
\hline
\end{tabular}


The table 2 showed that the percentage of the students' vocabulary in using noun, Diagnostic Test indicated that 3 students (8.11\%) got fairly, 15 students $(40.54 \%)$ got poor, 19 students $(51.35 \%)$ got very poor and none of students for the other classification.

In the cycle I, 3 students (8.11\%) got good, 15 students $(40.54 \%)$ got fairly , 16 students (43.24\%) got poor, 3students $(8.11 \%)$ got very poor and none of the students for the other classification. And, the cycle II, 5 students (13.51\%) got very good, 30 students $(81.08 \%)$ got good, 2 students $(5.40 \%)$ got fairly, and none of the students for the other classification.

To know the percentage of the students' achievement in vocabulary using nouns clearly, following chart was presented:

\section{Chart 2: The Percentage of the Students' Vocabulary noun}

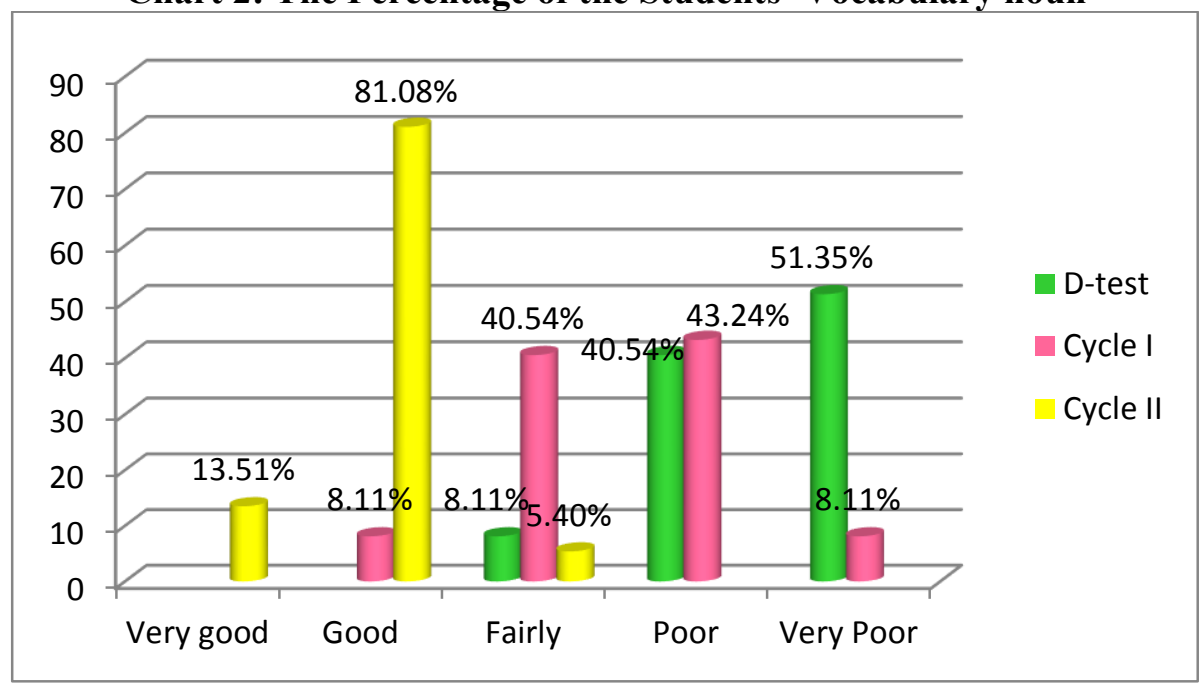

The chart above showed that the result of the students' vocabulary noun. After applying Incidental Vocabulary Acquisition in cycle II, the result of students' noun was higher than D-Test and cycle I where the students' achievement in cycle II was $13.51 \%$ categorized as very good, $81.08 \%$ categorized as good, $5.40 \%$ categorized as fairly and while in cycle I was lower than cycle II where the students' achievement in cycle I was $8.11 \%$ categorized good, $40.54 \%$ fairly, $43.24 \%$ poor and $8.11 \%$ categorized very poor. But the D-Test was the lowest where the students' achievement was $23.08 \%$ categorized fairly good, $61.54 \%$ categorized 
fairly, and $15.38 \%$ categorized as poor, , and none of students for the other classification.

Table 3. Percentage of the Students' Vocabulary in Using Adjective

\begin{tabular}{|c|c|c|c|c|c|c|c|c|}
\hline \multirow{3}{*}{ No } & \multirow{3}{*}{ Classification } & \multirow{3}{*}{ Score } & \multirow{2}{*}{\multicolumn{2}{|c|}{$\frac{\text { Non FC }}{\text { D-test }}$}} & \multicolumn{4}{|c|}{ The Application of FC } \\
\hline & & & & & \multicolumn{2}{|c|}{ Cycle I } & \multicolumn{2}{|c|}{ Cycle II } \\
\hline & & & Freq & $\%$ & Freq & $\%$ & Freq & $\%$ \\
\hline 1 & Very good & $91-100$ & - & & - & & 4 & $10.81 \%$ \\
\hline 2 & Good & $76-90$ & - & & 1 & $2.70 \%$ & 26 & $70.27 \%$ \\
\hline 3 & Fairly & $61-75$ & 2 & $5.41 \%$ & 12 & $32.43 \%$ & 7 & $18.91 \%$ \\
\hline 4 & Poor & $51-60$ & 16 & $43.24 \%$ & 19 & $51.35 \%$ & - & - \\
\hline 5 & Very Poor & $0-50$ & 19 & $51.35 \%$ & 5 & $13.51 \%$ & - & - \\
\hline \multicolumn{3}{|c|}{ Total } & 37 & $100 \%$ & 37 & $100 \%$ & 37 & $100 \%$ \\
\hline
\end{tabular}

The table 3 showed that the percentage of the students' vocabulary in using adjective, Diagnostic Test indicated that 2 students $(5.41 \%)$ got fairly , 16 students (43.24\%) got poor, 19 students $(51.35 \%)$ got very poor and none of students for the other classification.

In the cycle I, 1 students (2.70\%) got good, 12 students (32.43\%), got fairly, 19 students (51.35\%) got poor, 5 students (13.51\%) got very poor and none of the students for the other classification and then the cycle II, 4 students $(10.81 \%)$ got very good, 26 students $(70.27 \%)$ got good, 7 students $(19.91 \%)$ got fairly , and none of the students for the other classification.

To know the percentage of the students' achievement in vocabulary using verbs clearly, following chart was presented: 


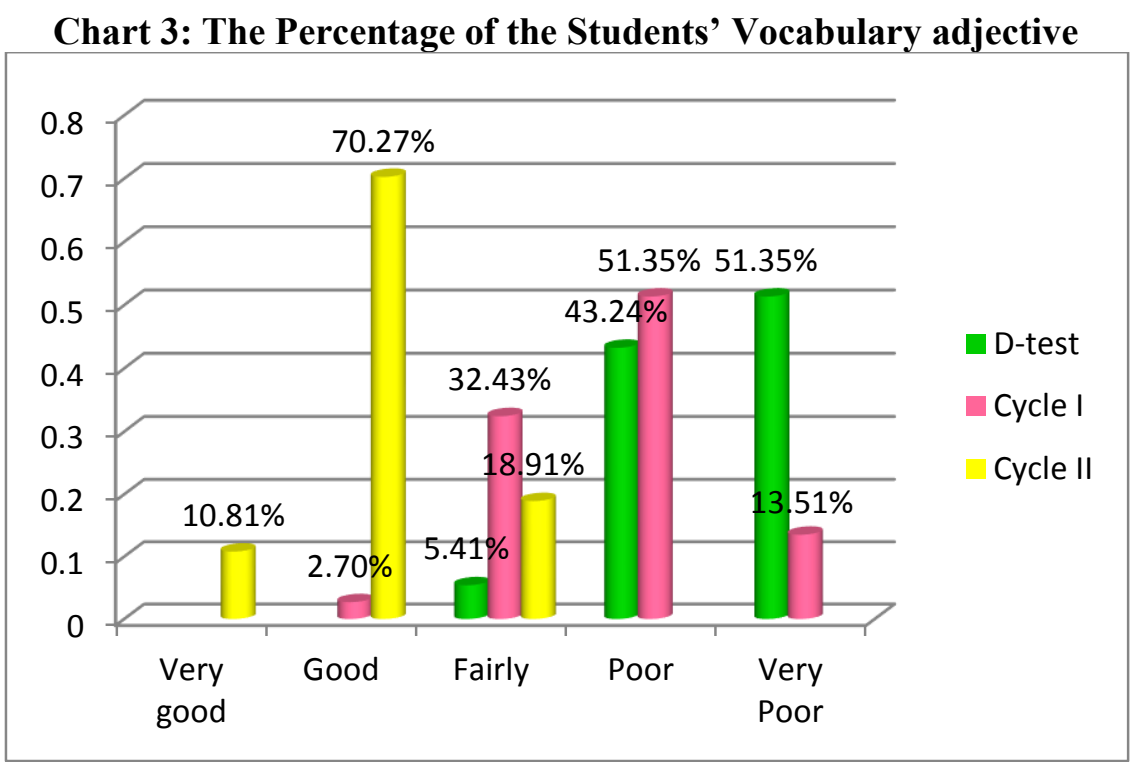

The chart above showed that the result of the students' vocabulary adjective. After applying Incidental Vocabulary Acquisition in cycle II, the result of students' adjective was higher than D-Test and cycle I where the students' achievement in cycle II was $10.81 \%$ categorized as very good, $70.27 \%$ categorized as good, $18.91 \%$ categorized as fairly. While in cycle I was lower than cycle II where the students' achievement in cycle I was $2.70 \%$ categorized good, $32.43 \%$ categorized as fairly, $51.35 \%$ categorized poor and $13,51 \%$ categorized very poor. But the D-Test was the lowest where the students' achievement was $5.41 \%$ categorized fairly, $43.24 \%$ categorized poor and $51.35 \%$ categorized as very poor, and none of students for the other classification.

\section{The percentage of the students vocabulary achievement}

\section{Achievement}

\section{Table 4. Percentage of the Students' Vocabulary}

\begin{tabular}{|c|c|c|c|c|c|c|c|c|}
\hline \multirow{2}{*}{ No } & \multirow{2}{*}{ Classification } & \multirow{2}{*}{ Score } & \multicolumn{2}{|c|}{ Non FC } & \multicolumn{3}{|c|}{ The Application of FC } \\
\cline { 4 - 9 } & & & \multicolumn{2}{|c|}{ D-test } & \multicolumn{2}{|c|}{ Cycle I } & \multicolumn{2}{c|}{ Cycle II } \\
\cline { 4 - 9 } & & Freq & $\%$ & Freq & $\%$ & Freq & $\%$ \\
\hline 2 & Very good & $\begin{array}{r}91- \\
100\end{array}$ & - & & - & & 5 & $13.51 \%$ \\
\hline 3 & Good & $76-90$ & - & & - & & 24 & $64.86 \%$ \\
\hline & Fairly & $61-75$ & 5 & $13.51 \%$ & 22 & $59.46 \%$ & 8 & $21.62 \%$ \\
\hline
\end{tabular}




\begin{tabular}{|c|c|c|c|c|c|c|c|c|}
\hline 4 & Poor & $51-60$ & 19 & $51.35 \%$ & 14 & $37.84 \%$ & - & \\
\hline 5 & Very Poor & $0-50$ & 13 & $35.13 \%$ & 1 & $2.70 \%$ & - & \\
\hline \multicolumn{3}{|c|}{ Total } & 37 & $100 \%$ & 37 & $100 \%$ & 37 & $100 \%$ \\
\hline
\end{tabular}

The table 4 showed that the percentage of the students' vocabulary achievement, Diagnostic Test indicated that 5 students (13.51\%) got fairly, 19 students (51.35\%) got poor, 13 students (51.35\%) got very poor and none of students for the other classification.

In the cycle I, 22 students (59.46\%) got fairly, 14 students $(37.84 \%)$ got poor , 1 students $(2.70 \%)$ got very poor, and none of the students for the other classification. And then the cycle II, 5 students (13.51\%) got very good, 24 students (64.86\%) got good, 8 students (21.62\%) got fairly, and none of the students for the other classification.

To know the percentage of the students' achievement in vocabulary achievement, following chart was presented:

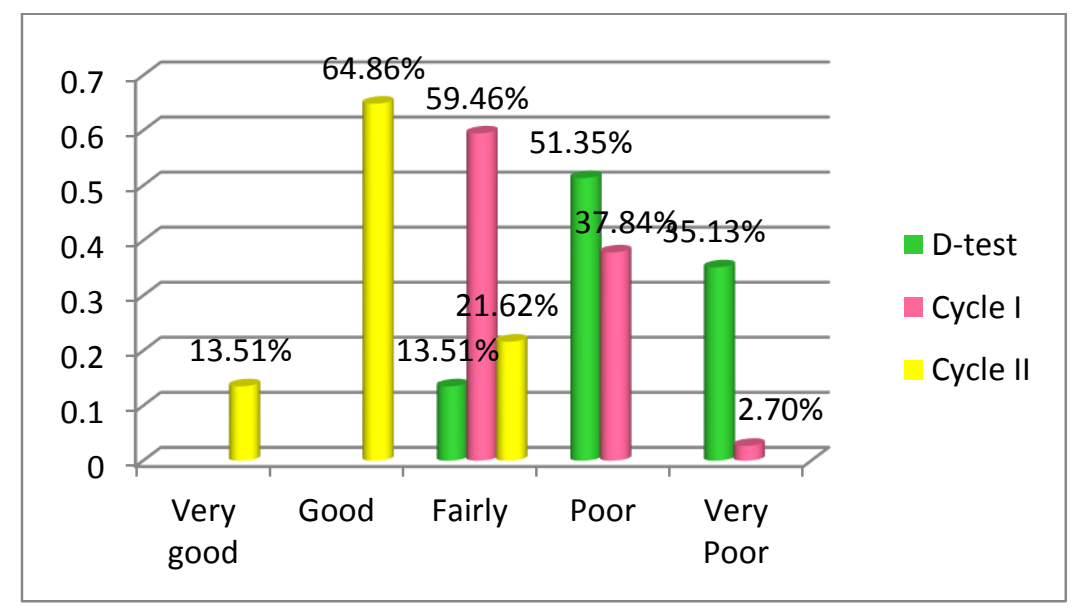

The chart above showed that the result of the students' vocabulary achievement. After applying Incidental Vocabulary Acquisition in cycle II, the result of students' vocabulary achievement was higher than D-Test and cycle I where the students' achievement in cycle II was $13.51 \% \%$ categorized as very good, $64.86 \%$ categorized as good, $21.62 \%$ categorized as fairly. While in cycle I was lower than cycle II where the students' achievement in cycle I was $59.46 \%$ categorized fairly, $37.84 \%$ categorized 
poor and $2.70 \%$ categorized Very poor. But the D-Test was the lowest where the students' achievement was $13.51 \%$ categorized fairly , $51.35 \%$ categorized poor and $35.13 \%$ categorized as very poor, and none of students for the other classification.

\section{The Result of the Students' Activity in Teaching and Learning Process.}

The result of observation of the students' activity in teaching and learning process toward the application of Incidental Vocabulary Acquisition in improving the students vocabulary mastery in finding Nouns and adjectives at the second of SMP Askari Pallangga in class VIIIc which is conducted in 2 cycle during 8 meeting is taken by the observer through observation sheet, it can be seen clearly through the following table

Table 5: The result of the students' activity in learning process.

\begin{tabular}{|c|c|c|c|c|c|}
\hline \multirow{2}{*}{ Cycle } & \multicolumn{5}{|c|}{ Meetings } \\
\cline { 2 - 5 } & I & II & III & IV & Mean Score \\
\hline I & $52.14 \%$ & $56.62 \%$ & $63.97 \%$ & $65.97 \%$ & $59.68 \%$ \\
\hline II & $70.71 \%$ & $70.45 \%$ & $80.30 \%$ & $81.76 \%$ & $75.56 \%$ \\
\hline
\end{tabular}

The result above is formulated based on the technique of data analysis and the students' score that are collected through observation sheet. The table above shows that the students' activity in cycle 1 improves normally, where at the first meeting in cycle I, the students' activity is $52.14 \%$ then increase to $56.62 \%$ at the second meeting, in the third meeting in cycle I, the students' activity improves to $63.97 \%$, and then in the fourth meeting the students' activity improves $65.97 \%$. the mean score of the students activity in cycle I is $59.68 \%$ This is caused by the teaching material is interesting for the students.

In cycle II, the students' activity improve normally, where at the first meeting in cycle II, the students' activity is $70.71 \%$ then increase to $70.45 \%$ at the second meeting, in the third meeting in cycle II, the students' activity improves to $80.30 \%$, and then in the fourth meeting the students' activity improves $81.76 \%$. This is caused by the teaching material is really 
interesting for the students. So the average of the students' activity in cycle II is $75.56 \%$.. It means that the students' participation is progress.

\section{A. Discussion}

The research had been done in two cycles and each cycles consists four meeting. To make this discussion clear, the researcher would like to explain the result of data analysis as follows:

Based on the result of data analysis of the test the students' vocabulary achievement of the data analysis of the second year students of SMP Askari Pallangga Gowa is still relatively low. So that to made thus discussion clear, the researcher would like to explain in two parts; (1) the students' vocabulary in using noun through Incidental Vocabulary Acquisition; (2) The students' vocabulary in using adjective through Incidental Vocabulary Acquisition.

The improvement of the students' vocabulary achievement through Incidental Vocabulary Acquisition had effect that was effective. Where the researcher found in cycle I, the mean score of students' vocabulary achievement in using noun was 64.86 and the cycle II the mean score is 86.49. While the research found in cycle I, the mean score of the students' vocabulary achievement in using adjectives was 62.43 and the cycle II the mean score was 83.51. It was good from the standard curriculum and target score that the researcher wants to achieve. Where standard curriculum is 65.00 and the target score is 70.00 . So, the target score could be achieved in the cycle II.

The result of the students' activeness also improved the first meeting until the last meeting for each cycle. The cycle $\mathrm{I}$ in the first meeting students' was $52.14 \%$, the second meeting the students' activeness was $56.62 \%$, and the third meeting of students' activeness was $63.97 \%$, and the last meeting was $65.97 \%$. And the averages of students' activeness in learning vocabulary of cycle I was $59.68 \%$. 
The result of the students' activeness the cycle II in the first meeting was $70.71 \%$, the second meeting of students' activeness was $70.45 \%$, then the third meeting was $80.30 \%$, and the last meeting was $81.76 \%$. And, the averages of students' activeness in learning vocabulary of cycle II was $75.56 \%$.

\section{CONCLUSION AND SUGGESTION}

\section{A. Conclusion}

Based on discussion that proposed in previous other chapters, inferential the following:

1. The improvement of the students' vocabulary in noun through the use of Incidental Vocabulary Acquisition at the second year students of SMP Askari Pallangga Gowa in cycle I, the mean score of students' vocabulary achievement in using noun was 64.86 and the cycle II the mean score is 86.49 .

2. The improvement of the students' vocabulary in adjectives through the use of Incidental Vocabulary Acquisition at the second year students of SMP Askari Pallangga Gowa cycle II, the mean score of students' vocabulary achievement in using adjectives was 62.43 and the cycle II the mean score was 83.51 .

3. The result of the students' activeness also improved the first meeting until the last meeting for each cycle. The cycle I the averages of students' activeness in learning vocabulary of cycle I was $59.68 \%$ and the averages of students' activeness in learning vocabulary of cycle II was $75.56 \%$.

\section{B. Suggestion}

To improve the vocabulary mastery command of the students' the writer puts forward some suggestions:

1. In teaching vocabulary, the teacher plays an important role. So, the teacher have to be creative to apply various kind of suitable strategy, in 
order the students will never bored, but they will be more interested in learning English.

2. The students should be highly motivated to know much vocabulary and use them in oral and written communication.

3. The writers in the future are suggested that they develop these research findings to investigate in learning and teaching vocabulary issues in any level of students. Moreover, the use of classroom action research as research design can be first research implication to secure the issues or problem in increasing the students' vocabulary mastery.

\section{REFERENCES}

Allen, Edward David Rebecca M. Vallate. 1977. Classroom Techniques as a second language. New York: Oxford University Press Inc.

Beck, Mckeown and McCaslin. 1983. Vocabulary Acquisition $1^{\text {st }}$ Edition. George Allen and Unwin (Publisher) ltd.

Beck, Mckeown and McCaslin. 1983. Vocabulary Acquisition $1^{\text {st }}$ Edition. George Allen and Unwin (Publisher) ltd.

Best, John W. (1981). Research in Education. Third Edition. New York: of America: Prentice-Hall, Inc., Englewood cliffs, New Jersey.

Coady, J.M (1993). Research on ESL/EFL. Vocabulary Acquisition:Parting it in context. In T. Huckin,M. Hybes, \& J.M Coady Second Language Reading and vocabulary learning (pp. 3-23).

Coudy, J.M. (1986). Vocabulary Acquisition: Mystery and Paradox, CA International TESCA.

Davies, E., and Whitney, N. 1984. Study for Skills. Students Book. London: Butter and Tanner.

Gay, LR. 1981. Educational Research: Competencies for analysis and Application. New York: Second Edition. Colombus: Charles E Merrill Publishing Company. 
Gairs, Ruth and Redman, Stuart. 1986. Working with Words. A Guide to Teaching and Learning Vocabulary. New York; Cambridge University Press

Good, Carter Victors. 1959. The Dictionary of Education. New York: Cambridge University Press.

Harmer, Jeremy. 1991. The principle of English Language Teaching. New York: Longman.

Harmer, Jeremy. 1991. The Practice of English Language Teaching. London: Longman Group. Hackin and Coady (1999). Incidental Vocabulary Acquisition. From http;//www.teachingvocabulary html.

Hornby, A.S. et.al. 2000. The Advances Learner's Dictionary to Current English. Second Edition. London: Oxford University Press.

Kagan, Spencer. 1994. Cooperative Learning. Kagan. San Clemente,CA: Kagan Publishing

Kustaryo, S. 1988. Reading Method for Colleague Students. Jakarta: Proyek Pengembangan Lembaga Pendidikan Tenaga Kependidikan, Direktorat

Krashen (1989). We Aquaire Vocabularyand Spelling by Reading Additional Endence for the Imput Hypotesis : The Modern Language Journal, 73 (4), 439-464.

Mikulecky, B. S. and L. Jeffries. 1986. Reading Power. Boston: Addison Wesley Publishing Company.

Nation Paul. 2005. Teaching Vocabulary. http://www.asian-efljournal.com/September_05_pn.php.

Nusakasuma, T., and Suyanto, K. 1996. Vocabulary and Structure. Jakarta: Depdikbud.

Nuttal, Christian. 1988. Teaching Reading Skill in a Foreign Language. London: Heineman Educational. Books Ltd.

Page, Terry \& Thomas, JB. 1973. International Dictionary of Education. New York: Nicholas Publisher Co. 
Reece, Ian and Walker, Stephen. 1997. Teaching, Training and Learning, A Practical Guide. Third Edition. Great Britain: Business Education Publishers.

Richards, J and Renandya, W. 2002. Methodology in Language Teaching, An Anthology of Current Practice. New York: Cambridge University Press.

Richards, J. 2000. Curriculum Development in Language Teaching. Cambridge: Cambridge University Press.

Richards, J. 2000. Series Editors Preface A Way with Words Resource Pack 1. Cambridge: Cambridge University Press.

Richards, Jack. Platt, John \& Weber, Heidi. 1985. Longman Dictionary of Applied Linguistics. England: Longman Group Ltd.

Rivers, W. 1971. Linguistic and Psychological Factors in Speech Perception and Their Implications for Teaching Materials: In Language in Education. Theory and Practice 20. Cambridge: Cambridge University Press, 11-2.

Schail, William. 1967. Seven Days to Faster Reading. New York: Paper Back Library.

Ur. Penny. 1996. A Course in Language Teaching, Practice and Theory. London: Cambridge University Press.

Wallace, Michael J. 1989. Teaching Vocabulary ELBS. New York: Oxford University Press Inc.

Webster, Noah. 1983. Webster Twenty Century of English Language. New York: Simon and Sthucher. 